\title{
廃棄物中ホウ素の存在形態と溶出性
}

\author{
吉永 淳 ${ }^{1)}$, 松脇 崇晃 ${ }^{2)}$, 長谷川陽一 ${ }^{1)}$, 柳沢 幸雄 ${ }^{1}$, \\ 貴田 晶子 ${ }^{3)}$, 松江 秀明), 米沢仲四郎 ${ }^{4)}$ \\ ${ }^{1)}$ 東京大学 大学院新領域創成科学研究科（下113-0033 東京都文京区本郷7-3-1） \\ ${ }^{2)}$ 東京大学 大学院工学系研究科（T113-8656 東京都文京区本郷7-3-1） \\ ${ }^{3}$ 広島県保健環境センター（テ734-0001 広島県広島市南区皆実町1-6-29） \\ ${ }^{4}$ 日本原子力研究所（†319-1195 茨城県那珂郡東海村白方白根2-4)
}

[平成14年 1 月 24 日受理］

\section{Chemical Fractionation and Leachability of Boron in Waste Samples}

\author{
Jun YOSHINAGA ${ }^{1 \text {, }}$, Taka-aki MATSUWAKI ${ }^{2)}$, Yoichi HASEGAWA ${ }^{1)}$, Yukio YANAGISAWA ${ }^{1)}$, \\ Akiko $\mathrm{KIDA}^{3)}$, Hideaki MATSUE ${ }^{4)}$ and Chushiro YONEZAWA ${ }^{4)}$ \\ ${ }^{1)}$ Institute of Environmental Studies, The University of Tokyo \\ (7-3-1 Hongo, Bunkyo, Tokyo 113-0033) \\ ${ }^{2)}$ Department of Chemical System Engineering, The University of Tokyo \\ (7-3-1 Hongo, Bunkyo, Tokyo 113-8656) \\ ${ }^{3)}$ Hiroshima Prefectural Health and Environment Center \\ (1-6-29 Minami, Minami, Hiroshima, Hiroshima 734-0001) \\ ${ }^{4)}$ Japan Atomic Energy Research Institute \\ (2-4 Shirakatashirane, Tokai, Naka, Ibaraki 319-1195)
}

[Received January 24, 2002]

\begin{abstract}
Summary
The leachability of boron in waste samples can vary both with boron content of the sample and with $\mathrm{pH}$ of the leachant. Boron leached more from dust, cinder and some waste ceramic samples when the solution was acidic, however, the mechanism of the leaching was not clear.

In order to better predict boron emission from waste landfill site into leachate, boron in waste samples (incineration ash, slag, waste glass etc) were fractioned (exchangable, carbonatebound, Fe-Mn oxide-bound, organic matter-bound and residual) by sequential extraction method followed by ICP atomic emission spectrometry and/or neutron guided prompt gamma ray analysis for the determination of boron in each fraction.

Distribution of boron among the five fractions differed from one sample to another. Correlation analysis of the results indicated that boron content in the "exchangeable" fraction was a better predictor of the leachability than was the total boron content of the sample.

Thermal treatment $\left(1300^{\circ} \mathrm{C}\right)$ of the waste samples altered the original distribution profile of boron in the samples: more boron was found in less leachable fraction. Thus the present results indicated that waste fusion is a preferable approach to lessen boron emission from waste into leachate after landfill.
\end{abstract}

Key words: Boron, Waste, Sequential extraction method, Leachability, Thermal treatment 


\section{1.はじめに}

多くの廃棄物埋立処分場浸出水が高濃度のホウ素を含 有していることが知られており るホウ素の環境負荷低減対策のために, 原因となる廃棄 物の特定が課題となっている。前報りにおいて筆者らは, 各種廃棄物のホウ素含有量 ·溶出量調査によって, 焼却 灰, 飛灰, 鉱涬, ガラス・陶磁器類抢よび強化プラス チック（FRP）が浸出水中ホウ素の起源として疑われる ことを報告した。これらの廃棄物のホウ素含有量は他の 廃棄物（污泥, 建築廃材, 一般プラスチックなど）に比 ベると統計学的に有意に高かったためである。ところ が, これらの廃棄物試料の環境庁告示法による溶出濃度 は他の廃棄物と統計学的な差がなかった。

この結果には溶出条件と廃棄物試料中ホウ素の存在形 態とが関与しているものと考えられる。貴田は焼却灰, 飛灰, ガラスくずについて溶出液の $\mathrm{pH}$ を変化させた実験 を行い, 溶出液の $\mathrm{pH}$ が低下するとホウ素溶出量が増加す ることを見出している3”。焼却灰や飛灰など，純水を用い た告示法で溶出すると溶出液の $\mathrm{pH}$ が10以上のアルカリ 性を示寸試料では, 中性条件に比べホウ素溶出量が低く なることは統計学的にも推定されている2゙。しかしながら 廃棄物試料中のホウ素がどのような形態で存在している のか, 存在形態の違いが溶出量の違いとどのような関係 にあるのか,はこれまで検討されたことがない。

そこで本研究では, 焼却灰, 飛灰以外にもホウ素溶出 源となりうる廃棄物試料について, 溶出液の $\mathrm{pH}$ がホウ 素溶出量に与える影響を実験的に調べた。さらに焼却 灰, 飛灰など主要な廃棄物試料に含まれるホウ素の存在 形態を, 逐次抽出法 (sequential extraction method) に より調べた。逐次抽出法はもともと地質試料中元素の存 在形態を, イオン交換態, 炭酸塩結合態, 鉄・マンガン 酸化物結合態, 有機物結合態, 残渣などに分画する方法 である ${ }^{4)}$ 。廃棄物中各分画に存在するホウ素量と告示法 による溶出量との関係を調べ, その結果を元に, ホウ素 溶出量を低減化する方策についても考察した。

\section{2. 試料と方法}

\section{1 ホウ秦溶出濃度と溶出液の $\mathrm{pH}$ の関係}

2. 1.1 試料

前報においてホウ素含有量, 溶出量を調査した廃棄物 試料のうち, 8 試料を使用した。試料はめのう乳鉢に よって粉砕後， $2 \mathrm{~mm}$ メッシュを通った部分を用いた。 試料のホウ素含有量, 告示法による溶出濃度を Table 1 に示す。

\section{1.2 方法}

溶出液として硝酸（超高純度，関東化学）を添加した 純水をもちいた以外は, 液固比 $(10: 1)$, 振とう時間
( 6 時間), 振とう回数 $(200$ 回 $/ \mathrm{min})$ などは環境庁告示 46 号による溶出試験方法に準じて溶出試験を行った。た だし溶出液への硝酸添加量, すなわち初期 $\mathrm{pH}$ は, 試料 によって異なる。告示法によってえられた溶出液の $\mathrm{pH}$

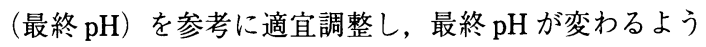
に設定した。

約 $0.1 \mathrm{M}$ の希硝酸（初期 $\mathrm{pH}=1.2 ） を$ 用いて飛灰につ いて溶出試験を行った際の $\mathrm{pH}$ の経時変化を Fig. 1に示 した。この図から明らかなように, $\mathrm{pH}$ は試験開始後 1 時間以内にはほほ最終 $\mathrm{pH}$ 付近まで上昇した。このこと は，振とう時間の大部分（たとえば 6 時間中の 5 時間） を最終 $\mathrm{pH}$ の溶媒で振とうしていたことを意味する。

焼却灰 $\mathrm{A}$, 飛灰 $\mathrm{B}$ について, $1 \mathrm{M}$ 硝酸を用いて溶出試 験を行った後, 固液分離を行う前にアンモニア水（超高 純度, 関東化学) を加えて溶媒の $\mathrm{pH}$ を再度アルカリ側 に調整し，さらに 6 時間振とうを続行した。

溶出液は遠心分離した後，一部をとって $\mathrm{pH}$ （最終

Table 1 Samples analyzed for B leachability as a function of extractant $\mathrm{pH}$

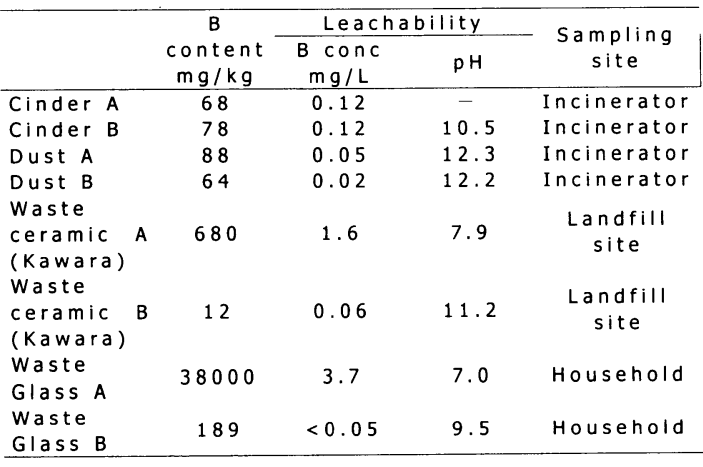

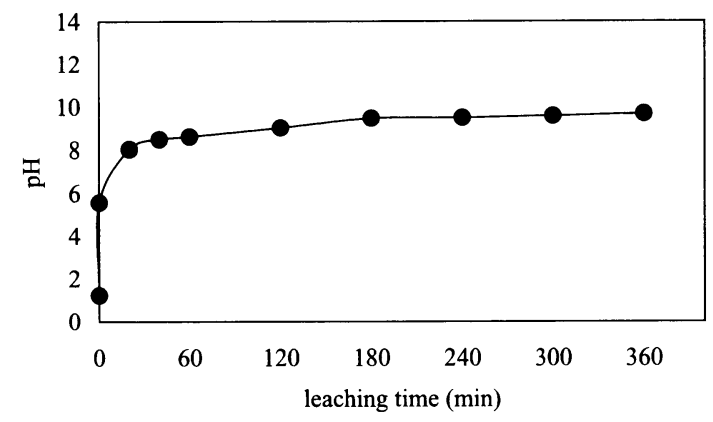

Fig. $1 \mathrm{pH}$ of the leachant as a function of leaching time

The leachant was dilute nitric acid (ca $0.1 \mathrm{M}$ ) of the initial $\mathrm{pH} 1.2$. Liquid $(\mathrm{L}) /$ solid $(\mathrm{kg})=10$ 
$\mathrm{pH}$ ）を測定し, 残りは $0.45 \mu \mathrm{m}$ のメンブランフィルター (ザルトリウス, ドイッ) でろ過し, 成分安定化のため に1 Mになるよう硝酸を加えた。ホウ素濃度はICP 発光 法（P-4010，日立）により測定した。

\section{2 廃棄物中ホウ秦の存在形態分析}

\section{2.1 試料}

前報においてホウ素含有量, 溶出量を測定した廃棄物 試料17試料を使用した。Table 2 に詳細を示した。試料は

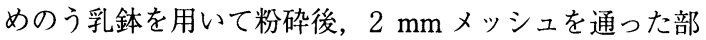
分を用いた。

\section{2.2 逐次抽出法}

Tessier らの方法 ${ }^{4}$ をベースにした逐次抽出法により， 「イオン交換態」,「炭酸塩結合態」,「鉄・マンガン酸化物 結合態」,「有機物結合態」,「残渣 (ケイ酸塩)」の 5 分画 に分けた。 $100 \mathrm{mg}$ の試料を $12 \mathrm{~m} \ell$ 容ポリプロピレン (PP) 製試験管に取り，以下の溶媒を順次加えて，所定の時間 振とうを行った。振とう後は遠心分離機にかけ，上澄み を別の PP 製試験管あるいは PP 製遠沈管 $(50 \mathrm{~m} \ell$ 容) に とり分けた。次の溶媒に移る前に純水を加えて再懸濁し て洗浄し, 遠心分離後, 上澄みは洗液としてホウ素定量

Table 2 Samples subjected to sequential extraction method

\begin{tabular}{|c|c|c|c|}
\hline & $\begin{array}{c}\text { B content } \\
\mathrm{mg} / \mathrm{kg}\end{array}$ & $\begin{array}{c}\text { B } \\
\text { leachability } \\
\mathrm{mg} / \mathrm{L}\end{array}$ & $\begin{array}{c}\text { Sample } \\
\text { description }\end{array}$ \\
\hline Dust C & 1157 & 32 & Coal fly ash \\
\hline Dust D & 178 & 5.4 & $\begin{array}{c}\text { Domestic } \\
\text { origin }\end{array}$ \\
\hline Dust $E$ & 185 & 2.3 & $\begin{array}{c}\text { Domestic } \\
\text { origin }\end{array}$ \\
\hline Cinder $A^{*}$ & 68 & 0.12 & $\begin{array}{c}\text { Domestic } \\
\text { origin }\end{array}$ \\
\hline Cinder D & 130 & 1.9 & $\begin{array}{c}\text { Industrial } \\
\text { origin }\end{array}$ \\
\hline Cinder $E$ & 62 & 0.47 & $\begin{array}{c}\text { Domestic } \\
\text { origin }\end{array}$ \\
\hline Slag A & 103 & 1.2 & $\begin{array}{c}\text { Blast } \\
\text { Furnace }\end{array}$ \\
\hline Slag B & 555 & 8.1 & $\begin{array}{c}\text { Automotive } \\
\text { industry }\end{array}$ \\
\hline Slag C & 166 & 0.95 & $\begin{array}{c}\text { Electric Arc } \\
\text { Furnace }\end{array}$ \\
\hline $\begin{array}{l}\text { Waste glass } \\
\text { A* }^{*}\end{array}$ & 38000 & 3.7 & Pyrex ${ }^{R}$ \\
\hline $\begin{array}{l}\text { Waste glass } \\
\text { C }\end{array}$ & 77 & 0.21 & $\begin{array}{c}\text { Reagent } \\
\text { bottle }\end{array}$ \\
\hline $\begin{array}{l}\text { Waste } \\
\text { ceramic C }\end{array}$ & 44 & 0.23 & Dish \\
\hline $\begin{array}{l}\text { Waste } \\
\text { ceramic D }\end{array}$ & 324 & 0.30 & Bowl \\
\hline Sludge A & 12 & 0.49 & $\begin{array}{l}\text { Sewage } \\
\text { sludge }\end{array}$ \\
\hline Sludge B & 15 & 0.22 & $\begin{array}{c}\text { Sewage } \\
\text { sludge }\end{array}$ \\
\hline $\begin{array}{l}\text { Fused Slag } \\
\text { A }\end{array}$ & 144 & $<0.05$ & $\begin{array}{c}\text { Details not } \\
\text { known }\end{array}$ \\
\hline $\begin{array}{l}\text { Fused Slag } \\
\text { B }\end{array}$ & 351 & $<0.05$ & $\begin{array}{c}\text { Details not } \\
\text { known }\end{array}$ \\
\hline
\end{tabular}

を行った。なお洗液中のホウ素量は, 直前の分画中のホ ウ素量に加算した。

(1)フラクション1（「イオン交換態」）

純水 $10 \mathrm{~m} \ell$ で振とう 2 時間, を 3 回行った後, $0.1 \mathrm{M}$ 塩 化カルシウム水溶液 $10 \mathrm{~m} \ell$ で振とう 16 時間（室温）。以上 を合わせて「イオン交換態」ホウ素とした。Tessierらの 方法には純水振とうは含まれていない。実際には水溶性 分画に含まれるホウ素もこのフラクションに含まれると 考えられる。

(2)フラクション 2 (「炭酸塩結合態」)

酢酸で $\mathrm{pH}$ を 5 に調整した $1 \mathrm{M}$ 酢酸アンモニウム水溶 液 $8 \mathrm{~m} \ell$ で振とう 5 時間 (室温)。

(3)フラクション 3 (「 $\mathrm{Fe}-\mathrm{Mn}$ 酸化物結合態」)

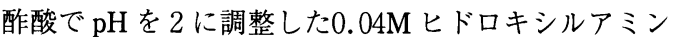
水溶液 $20 \mathrm{~m} \ell$ で振とう 6 時間 $\left(96 \pm 3{ }^{\circ} \mathrm{C}\right)$ 。

(4)フラクション 4 (「有機物結合態」)

硝酸で $\mathrm{pH} 2$ に調整した $0.02 \mathrm{M}$ 硝酸 $+30 \%$ 過酸化水素水 $8 \mathrm{~m} \ell$ で振とう 5 時間 $\left(85 \pm 5{ }^{\circ} \mathrm{C}\right)$ 後, $20 \%$ 硝酸によっ て $3.2 \mathrm{M}$ に調整した酢酸アンモニウム水溶液 $5 \mathrm{~m} \ell$ を加 えて振とう0.5時間 (室温)。

(5)フラクション 5 (「ケイ酸塩結合態」)

(1)から(4)を行った後に残る残渣。

なお，各分画の名称は地質試料を対象とした場合の Tessierらの呼称に従ったもので, 本研究での対象試料 は廃棄物であることから, 必ずしもこの名称が実際の分 画を適切に表すものではない可能性がある。

使用した試薬類は，硝酸，酢酸については超高純度， 過酸化水素水は原子吸光用, その他は特級試薬で, すべ て関東化学製である。

(1)～(4)の分画中拈よび洗液中ホウ素濃度は, ICP 発光 法により測定した。各分画で用いた溶媒でホウ素標準液 を作製する，マトリックスマッチング法によって作成し た検量線を定量に用いた。(5)のケイ酸塩分画中ホウ素濃 度は, 残渣を $85^{\circ} \mathrm{C}$ で乾燥後回収し, 即発ガンマ線分析を 行った2,5)。

\section{3 高温処理}

Table 2にあげた試料のうち，14試料について，3〜 $5 \mathrm{~g}$ を高純度アルミナ製容器にとり, 電気炉 (SL$1415 \mathrm{C}$ ，モトヤマ(株) を用いて $1300^{\circ} \mathrm{C}$ で 1 時間処理した 後, 逐次抽出法で各分画中のホウ素を抽出し, ICP 発光 法で各画分のホウ素濃度を定量した。このうち 4 試料に ついては高温処理前後の試料重量を測定して, 高温処理 に伴う重量変化を算出し, 各分画中のホウ素濃度を補正 した。 


\section{3. 結果と考察}

\section{1 廃棄物からのホウ亲溶出墛度と溶出液の最終 $\mathrm{pH}$ との関係}

Fig. 2a-c にホウ素溶出量 $(\mathrm{mg} / \mathrm{l})$ と溶出液の最終 $\mathrm{pH}$ の関係を眓示した。焼却灰, 飛灰, 廃陶磁器類（瓦）は 最終 $\mathrm{pH}$ の低下に伴って直線的にホウ素溶出濃度が上昇 したが, 廃ガラスは $\mathrm{pH}$ に関わらず溶出濃度はほほ一定 であった。焼却灰, 飛灰の結果は貴田の報告3) と一致し ている。貴田はガラスの溶出濃度も $\mathrm{pH}$ が中性から離れ ると酸性でもアルカリ性でも微増することを見出してい るが，今回の結果にはそのような傾向は見出せなかっ た。実験点数が少なかったせいであると考えられる。

溶出液の $\mathrm{pH}$ が低下するとより多くのホウ素が溶出す るメカニズムはこれまで明らかにされてこなかった。ホ ウ素は水溶液中ではホウ酸 $\left(\mathrm{H}_{3} \mathrm{BO}_{3}\right)$ の形で存在するが, その化学形態が $\mathrm{pH}=7$ より酸性側では $\mathrm{B}(\mathrm{OH})_{3}, \mathrm{pH}=$ 11 よりアルカリ側では B $(\mathrm{OH})_{4}{ }^{-}$がそれぞれ $100 \%$ であ $\eta^{6)}$, 後者の形態は土壤粒子表面への吸着性を示す こと はよく知られている。こうした知見を元に，可能性のひ とつとしてわれわれは, $\mathrm{pH}$ 低下に伴って B $(\mathrm{OH})_{3}$ の形態 のホウ素が増加し, 焼却灰や飛灰などの粒子表面からの 脱着が増加する，というメカニズムを想定した2)。しかし Fig. 2a, bを見る限り, ホウ素溶出濃度と最終 $\mathrm{pH}$ は直線 的な関係にあり, $\mathrm{pH}=7$ より酸性側でも $\mathrm{pH}$ の低下とと もに溶出濃度は上昇している。したがって少なくとも $\mathrm{pH}<7$ の酸性領域での溶出濃度の上昇は, 試料表面に 吸着していたホウ素が $\mathrm{B}(\mathrm{OH})_{3}$ の形で脱着したとは説明 できない。試料の構造中に取り込まれていたホウ素が, $\mathrm{pH}$ の低下に伴って試料の構造が変化する（溶解する, など）のにあわせて溶液中に溶出する，と考える方がよ り適切であろう。後で示すように，逐次抽出のデー夕か らも廃棄物試料には試料表面にクーロン力で吸着してい るイオン交換態のホウ素以外の画分にもホウ素が含まれ ていることが明らかである。

$1 \mathrm{M}$ 硝酸で焼却灰 $\mathrm{A}$ および飛灰 $\mathrm{B}$ からホウ素を溶出さ せた後, 溶出液にアンモニア水を加えて溶出液の $\mathrm{pH}$ を 上昇させたときの溶出液中ホウ素濃度と最終 $\mathrm{pH}$ との関 係を Fig. 3に図示した。図中の曲線は Fig. 2a， b に示し た焼却灰 $\mathrm{A}$, 飛灰 B からのホウ素溶出の $\mathrm{pH}$ 依存性デー 夕の近似曲線である。溶出液の最終 $\mathrm{pH}$ 上昇させると, $\mathrm{pH}$ の上昇に伴って溶出液中のホウ素濃度は低下するこ とが明らかである。また, 希硝酸で溶出した後, 焼却 灰, 飛灰と溶出液を分離し, 溶出液のみをアルカリ性に した場合も Fig. 3a，b とまったく同じ結果が得られた。 これらの実験結果は, 溶出液の $\mathrm{pH}$ 上昇に伴い, $\mathrm{B}(\mathrm{OH})_{4}{ }^{-}$ の割合が増加し，灰粒子あるいはアルミニウムや鉄の水 酸化物への吸着, 共沈等によって液相から固相へホウ素
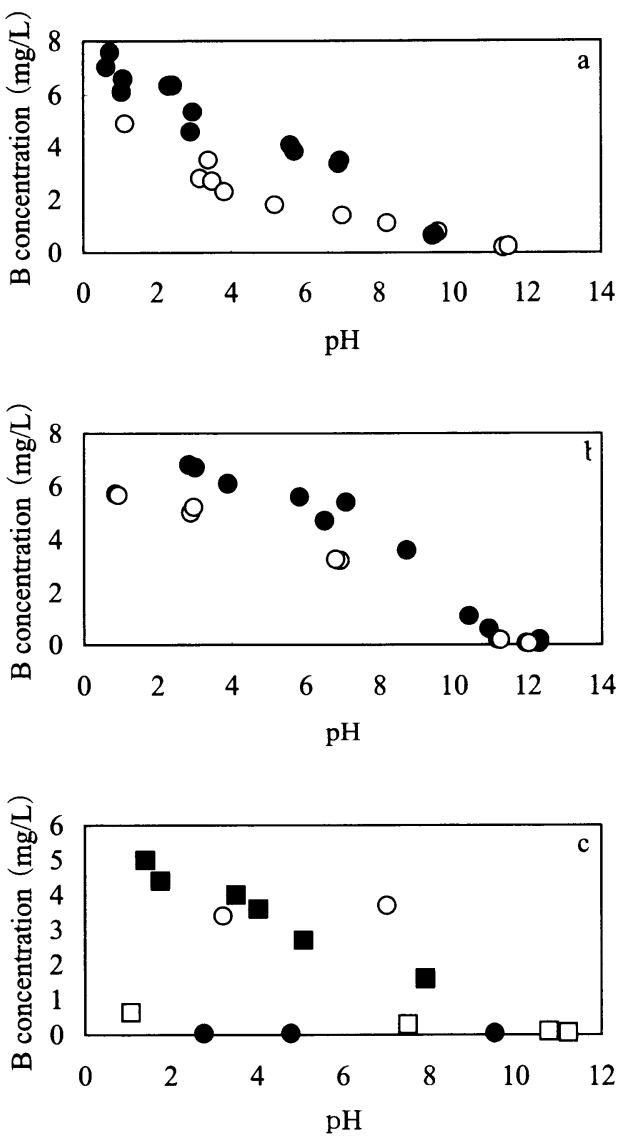

Fig. 2 Boron concentration $(\mathrm{mg} / \mathrm{l})$ in the leachant as a function of the final $\mathrm{pH}$

a, cinder: $O$, cinder A $\bigcirc$, cinder B. b, dust: , dust $A, \bigcirc$, dust B. c, waste ceramic and glass: $\bigcirc$, waste glass $A, \quad$, waste glass $B, \square$, waste ceramic A, $\square$, waste ceramic B. See Table 1 for sample description.

が移行するためであると考えられる。

しかも $\mathrm{pH}$ 上昇に伴うホウ素濃度低下プロファイルは, Fig. 3中に示した近似曲線とほほ一致したものであった。 Fig. 3のデー夕は, 焼却灰, 飛灰からのホウ素の溶出と, 溶液から灰試料等へのホウ素の再吸着は, $\mathrm{pH}$ のをパラ メータとした，同じメカニズムによって支配されている ことを示唆している。しかし先ほども述べたように，試 料からの溶出の $\mathrm{pH}$ 依存性は試料粒子表面への吸着ホウ

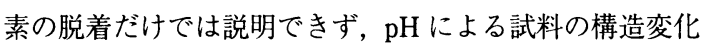
も重要な要因であるので, Fig. 3に見られたプロファイル の一致の持つ意味は現在のところ明らかではない。

以上のように, 試料からのホウ素の溶出 (脱着) ・吸着 挙動には $\mathrm{pH}$ が大きな影響をもつことは明らかであるも のの, その詳細なメカニズムについては今後より一層の 
a

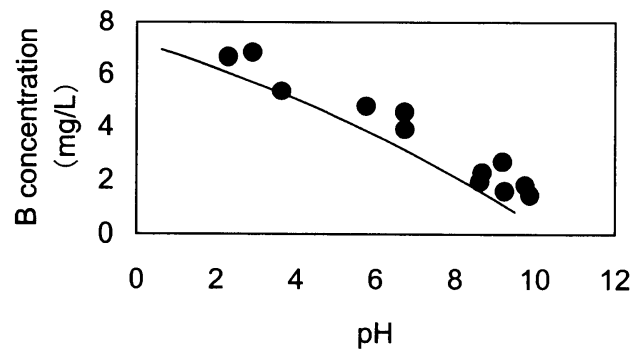

b

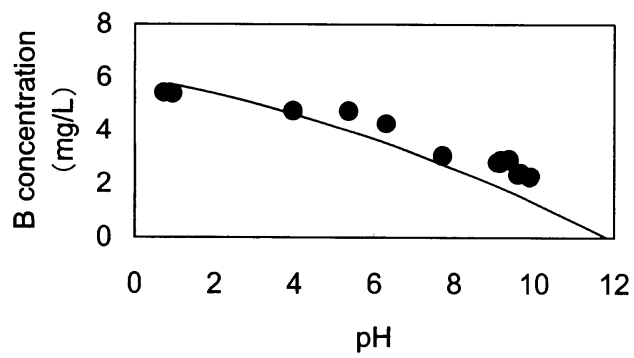

Fig. 3 Boron concentration $(\mathrm{mg} / \ell)$ in the leachant as a function of the final leachant $\mathrm{pH}$ $\mathrm{a}$, cinder $\mathrm{A} ; \mathrm{b}$, dust $\mathrm{B}$. The original leachant was $1 \mathrm{M}$ nitric acid and it was alkalinized after leaching with a varying volume of $\mathrm{NH}_{4} \mathrm{OH}$. The approximation curves in the figures were adopted from Fig. 2: leached B from the same sample when acidifying final leachant $\mathrm{pH}$.

検討が必要である。

一方, Fig. 3の結果は, 凝集沈殿による排水等からの ホウ素除去の可能性を示唆している。実際, 凝集沈殿に よるホウ素の除去法についてはすでに多くの検討がされ

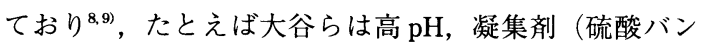
ド）高注入量においては一定の除去効果を認めたが，実 用性には乏しいと結論している8)。

\section{2 逐次抽出法による廃棄物中ホウ素の分画}

Fig. 4-1 4-7に逐次抽出法によって分画したホウ素 の分布割合を示した。「イオン交換態」(フラクション 1）のホウ素は, 飛灰, 焼却灰, 鉱涬, 污泥などに含ま れるが，ガラスや陶磁器，溶融鉱涬にはほとんど含まれ ない。ガラス, 溶融鉱涬の場合, ほとんどのホウ素が 「ケイ酸塩分画」(フラクション 5 ) に存在する。以上の ようなカテゴリーごとの大まかな傾向は存在するもの の, 同じカテゴリーでも試料によってホウ素の分布が異 なることは明らかであり, 廃棄物中ホウ素の分布につい
Dust C
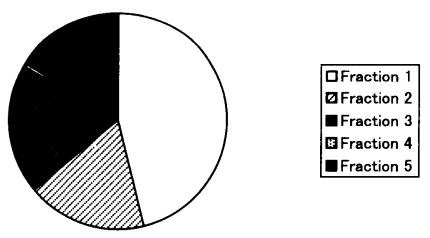

Dust D

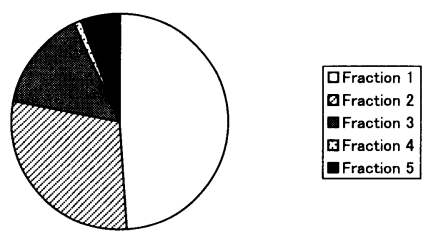

Dust $\mathrm{E}$
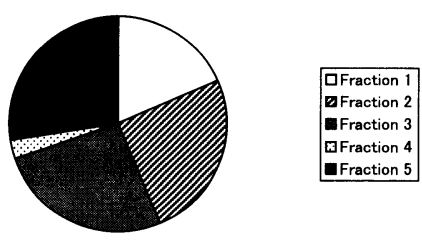

Fig. 4-1 Relative abundance of $B$ in the 5 fractions of dust samples. Detailed sample description is given in Table 2

てカテゴリーごとに一般化することは困難であることが 判明した。

なお Fig. 5に示したように，逐次抽出法で求められた 分画ごとのホウ素濃度の和と, 即発ガンマ線分析で求め たその廃棄物試料のホウ素含有量とはきわめてよく一致 した $(\mathrm{r}=0.998)$ 。このことは逐次抽出法によるホウ素 測定值の信頼性を間接的に示したものである。

本研究で用いた逐次抽出法では, 水やイオン強度の高 い溶媒で溶出する「イオン交換態」ホウ素（フラクショ ン1）が環境中でもっとも溶出しやすい分画で, 以下フ ラクション 2 から 5 にかけて, この順番にしたがって環 境中で溶出しにくい分画となると考えることができる (方法2-2参照)。しかし埋立処分場では, 埋立廃棄物の 種類や埋立方法によって，還元的・酸化的などあらゆる 条件になりうると想定しておくべきであり，したがって 安全サイドに立つならば, 逐次抽出法による「ケイ酸塩 分画」(フラクション 5 ) 以外の分画に存在するホウ素は 浸出水を介した潜在的環境污染源となる，と考えておく ことが必要であろう。Fig. 6は Table 2に示した17試料に 
Cinder A
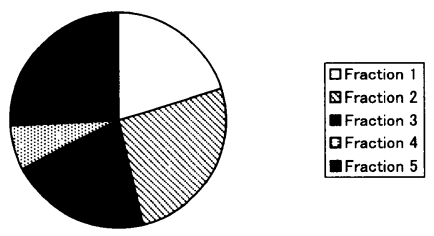

Cinder D
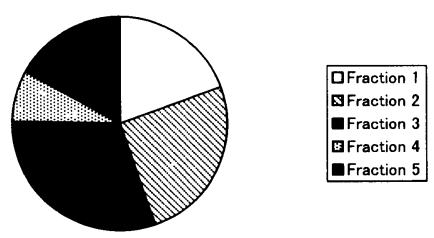

Cinder E
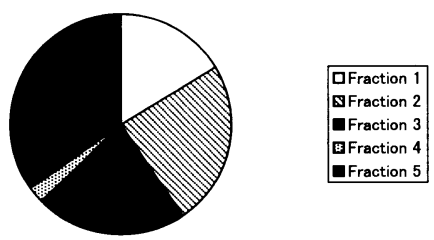

Eraction 5

Fig. 4-2 Relative abundance of $\mathrm{B}$ in the 5 fractions of cinder samples. Detailed sample description is given in Table 2

\section{Waste Glass A}
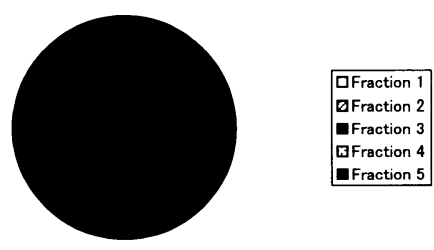

\section{Waste Glass C}
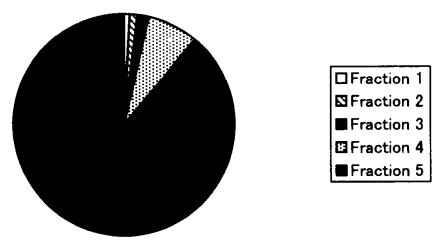

Fig. 4-4 Relative abundance of $\mathrm{B}$ in the 5 fractions of waste glass samples. Detailed sample description is given in Table 2
Slag A

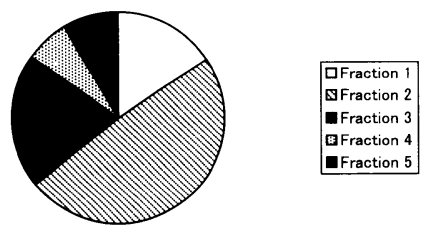

Slag B

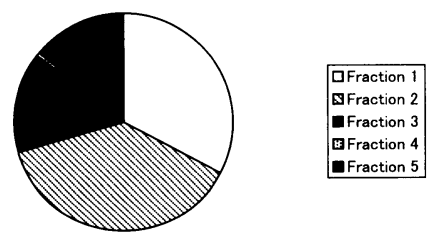

Slag C

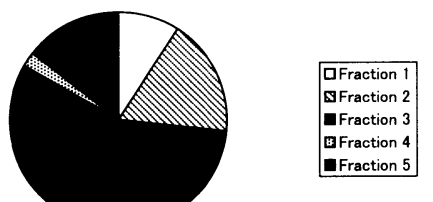

Fig. 4-3 Relative abundance of $\mathrm{B}$ in the 5 fractions of slag samples. Detailed sample description is given in Table 2

Waste Ceramic C
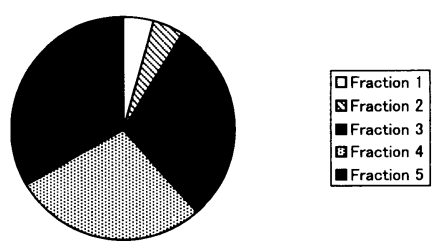

Waste Ceramic D
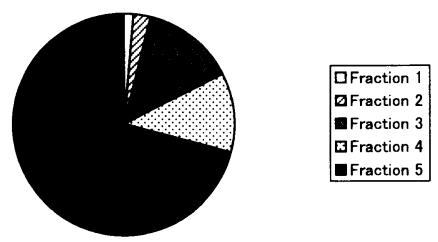

Fig. 4-5 Relative abundance of $B$ in the 5 fractions of waste ceramic samples. Detailed sample description is given in Table 2 
Sludge A

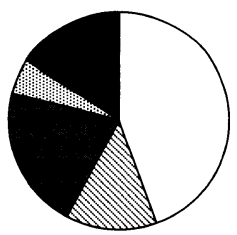

Graction

Fraction 2

Traction 4

Fraction 5

Sludge B

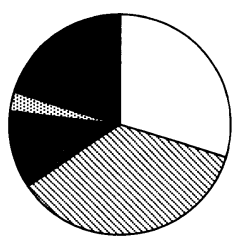

\begin{tabular}{|l|}
\hline Graction 1 \\
QFraction 2 \\
Graction 3 \\
GFraction 4 \\
Graction 5 \\
\hline
\end{tabular}

Fig. 4-6 Relative abundance of $B$ in the 5 fractions of sludge samples. Detailed sample description is given in Table 2

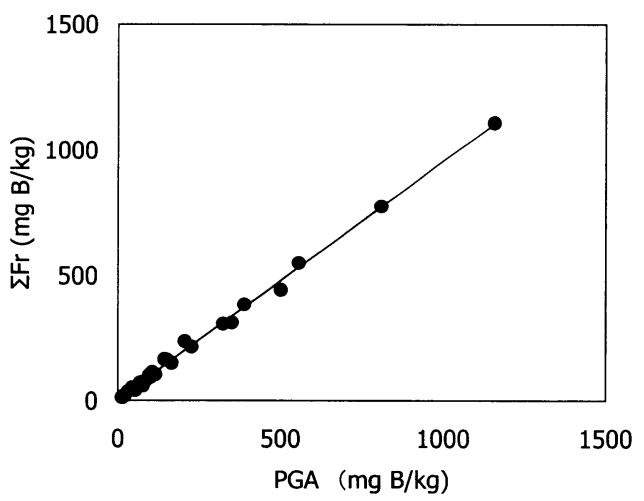

Fig. 5 Comparison of boron concentration (mg/kg) in waste samples as determined by prompt gamma-ray analysis (PGA) and by summing boron concentrations in the 5 fractions ( $\Sigma$ Fr). Regression equation was $\Sigma \mathrm{Fr}=0.952 \times$ $\mathrm{PGA}+4.048(\mathrm{r}=0.998)$.

ついて, 含有量 (a),「ケイ酸塩分画」以外 ( 、フラク ション 1〜4) に存在するホウ素量 (b), 「イオン交換態」 ホウ素量 (フラクション 1) (c) それぞれと, 環境庁告示 46号による溶出濃度との関係を示したものである。フラ クション $1 \sim 4$ 合計量と 46 号溶出濃度との相関 (b, r = 0.583) は, 試料のホウ素含有量と溶出濃度との相関 $(a, r$ $=0.483)$ よりはよいものの, 決定係数 $\mathrm{R}^{2}=0.340$ と, 全 体の変動の 3 分の 1 程度しか説明することができない。
Fused Slag A
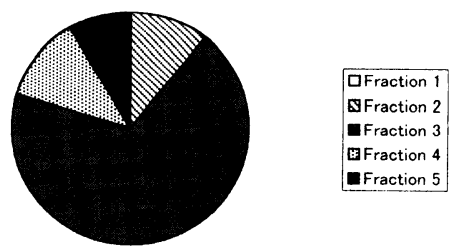

Fused Slag B

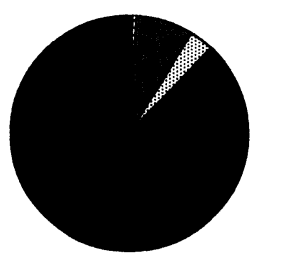

\begin{tabular}{|l|}
\hline Fraction 1 \\
QFraction 2 \\
EFraction 3 \\
GFraction 4 \\
EFraction 5 \\
\hline
\end{tabular}

Fig. 4-7 Relative abundance of $B$ in the 5 fractions of fused slag samples. Detailed sample description is given in Table 2

したがって試料の持つ潜在的溶出可能ホウ素量（ クション 1〜4) を予測するには46号試験では不十分で あることは明らかである。一方，「イオン交換態」分画 であるフラクション 1 のホウ素濃度と46号溶出濃度とは 高い相関があり (c, r =0.877), 以上のことから，46号 試験法は比較的短期のホウ素溶出量を予測するのによい 方法であるが，長期の溶出予測には不適である，という ことができよう。

\section{3 高温処理によるホウ素存在形態の変化}

$1300^{\circ} \mathrm{C} ， 1$ 時間の高温処理による廃棄物中ホウ素の分 画の変化を, 飛灰, ガラス, 陶磁器の例について Fig. 7 に示した。この図の縦軸はホウ素濃度をあらわしてお り, 高温処理後の各分画中のホウ素濃度は, 処理前後の 重量変化で補正して, 処理前の試料ベースに換算してあ る。一方 Fig. 8には, 高温処理による重量変化を補正し ていない, 焼却灰, 鉱㳯のホウ素分画の変化を示した。 高温処理後の試料 $1 \mathrm{~g}$ がもとの廃棄物試料何グラムに相 当するかが不明なため, 縦軸は無単位になっている。以 上のようにFig. 8については処理前後の分布変化を定量 的に評価することはできないが, 高温処理前後の分布割 合の変化は評価可能である。

高温処理後のホウ素含有量が減少している試料は, 処 理過程でホウ素が揮散していることを示すものである (Fig. 7飛灰D, Fig. 8鉱滓 B)。Fig. 8の鉱漳 Aだけは例外 であるが，他のすべての試料では高温処理によってホウ 素の分布は変化した。一般的には高温処理後は「イオン 
a

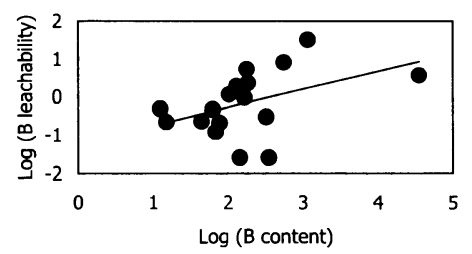

b

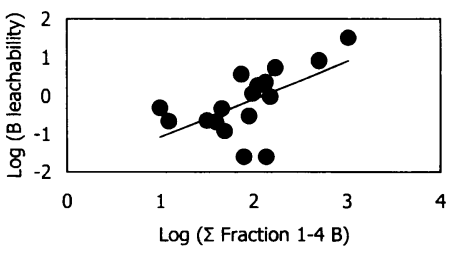

c

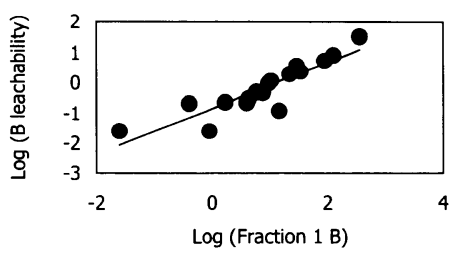

Fig. 6 Correlation between boron leachability as tested according to leaching procedure of Environmental Agency Notification 46 and a, total boron content of the sample $\left(\mathrm{R}^{2}=\right.$ $0.192)$, b, sum of boron contents in the 14 fractions obtained by the sequential extraction method (see text) $\left(\mathrm{R}^{2}=0.340\right)$, and $\mathrm{c}$, boron content of the fraction 1 $\left(\mathrm{R}^{2}=0.797\right)$.

交換態」(フラクション 1) や「炭酸塩結合態」(フラク ション 2）の割合が減少し, 代わりに「ケイ酸塩結合 態」(フラクション 5 ) の割合が増加する。前にも述べ たように，フラクション 1,2 は環境中で溶出しやすいホ ウ素であり, フラクション 5 は溶出しないと考えてよい 分画である。したがって高温処理によって廃棄物試料中 のホウ素はより溶出しにくい分画に分布することが明ら かとなった。

これは高温処理によって, 試料のケイ酸塩が溶解し, 再度冷却固化する際に, 揮散せずに残ったホウ素がケイ 酸塩骨格に取り达まれるためであると考えられる。高温 処理（溶融処理）は，重金属およびダイオキシン対策の ための焼却灰・飛疢の安定化処理法として用いられるよ うになってきているが, 本研究の結果は, ホウ素の溶出 抑制にも効果があることを示したものである。ただし，
Dust D

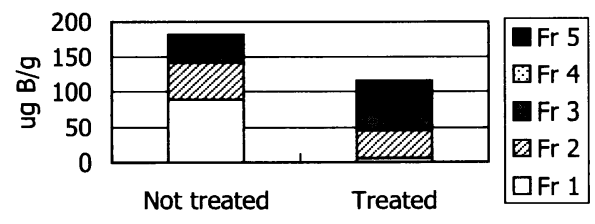

Dust $\mathrm{E}$

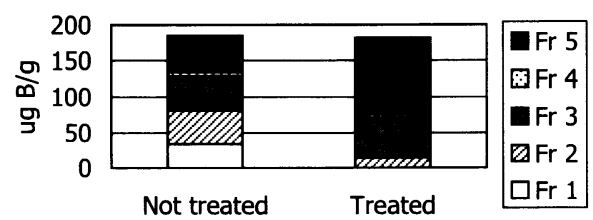

Waste Glass A

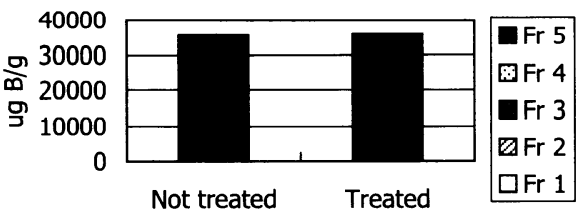

Waste Ceramics D

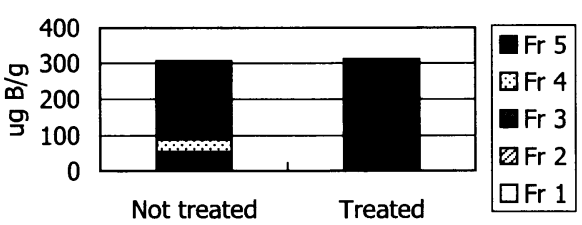

Fig. 7 Distribution of boron among the 5 fractions before and after thermal treatment (1300 ${ }^{\circ} \mathrm{C}$ for $\left.1 \mathrm{hrs}\right)$. Weight loss of the sample due to the treatment was corrected.

高温処理過程でのホウ素の揮散がある試料については, 飛散防止に努める必要がある。また鉱涬 $\mathrm{A}$ のように高温 処理をしてもホウ素の分布が変わらない試料も存在す る。これは試料の組成（たとえばケイ酸塩含有量など） によるものと考えられ, 焼却灰, 飛灰以外の廃棄物への 適用にはまだ検討の余地があろう。

\section{謝 辞}

東京大学工学系研究科化学システム工学専攻高橋研究 室の電気炉を使用させていただきました。感謝します。 即発ガンマ線分析は, 日本原子力研究所との「中性子ラ ジオグラフィ・中性子即発ガンマ線分析装置を利用する 研究」の協力研究の一環として行われた。 
a Dust C

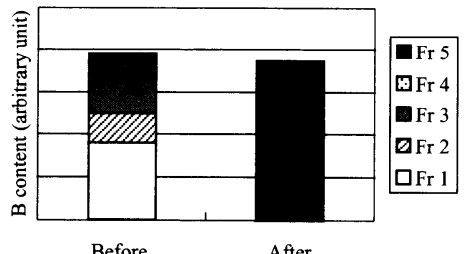

d Cinder E

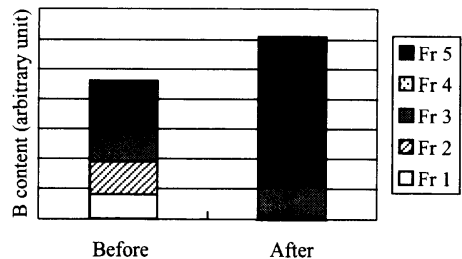

g Slag C

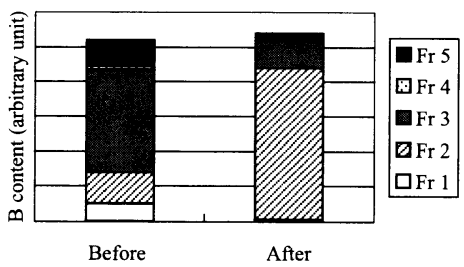

b Cinder C

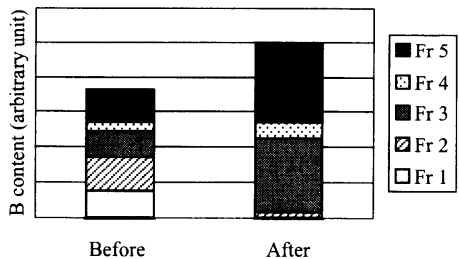

e Slag A

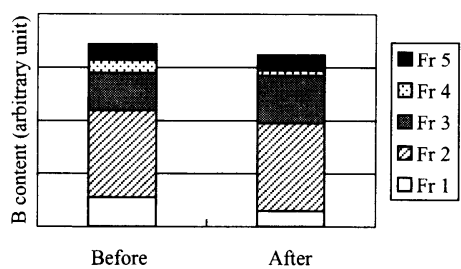

h Waste Glass A

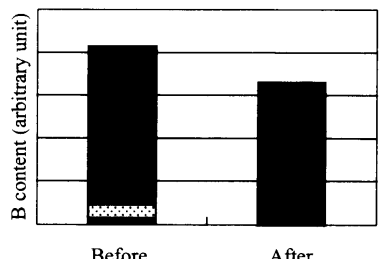

c Cinder D

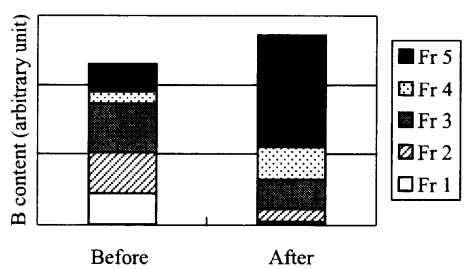

f Slag B

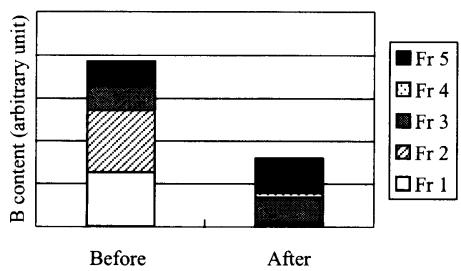

i Waste Ceramic A

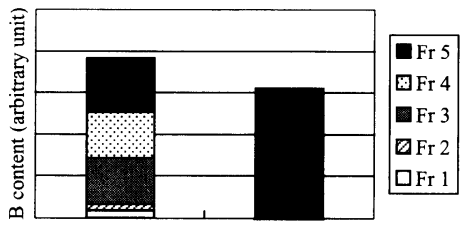

After
Before

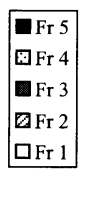

Fig. 8 Distribution of boron among the 5 fractions before and after thermal treatment (1300 ${ }^{\circ} \mathrm{C}$ for $1 \mathrm{hrs}$ ). Weight loss of the sample due to the treatment was not corrected; unit for the vertical axis is arbitrary.

\section{要 約}

飛疢, 焼却灰, 廃ガラス, 廃陶磁器類を試料として, 溶出液の $\mathrm{pH}$ とホウ素溶出濃度との関係を調べた。溶出 液の $\mathrm{pH}$ が低いほどホウ素の溶出濃度は高く，また一度 溶出したホウ素は, 溶出液の $\mathrm{pH}$ を上昇させると再吸着 か水酸化物への吸着 ·共沈によって液相から失われるこ とが判明した。ホウ素の溶出・吸着には $\mathrm{pH}$ が大きな影 響をもつことが再確認されたが，そのメカニズムは不明 である。

逐次抽出法と ICP 発光法・即発ガンマ線分析を組み合 わせて各種廃棄物に含まれるホウ素の分画（「イオン交 換態」,「炭酸塩結合態」,「Fe-Mn 酸化物結合態」,「有機 物結合態」,「ケイ酸塩結合態」）を行った結果, 飛灰な どはもっとも溶出しやすい「イオン交換態」に，ガラ ス・溶融鉱涬は最も溶出しにくい「ケイ酸塩」分画に, それぞれ多くのホウ素を含む傾向があった。しかし同じ カテゴリーの廃棄物でも試料によって 5 分画の相対存在
度が異なり，カテゴリーごとに一般化することはできな かった。告示46号試験法による溶出量は「イオン交換 態」分画に存在するホウ素量をよく説明できたが，潜在 的に溶出可能なホウ素量を予測するには不十分であっ た。鉱滓以外の廃棄物は, 高温 $\left(1300^{\circ} \mathrm{C}\right)$ 処理によって 試料中ホウ素が「ケイ酸塩」分画に移行し, 溶出しにく くなり, 試料を溶融後に埋め立てることでホウ素溶出を 低減できることが示唆された。

\section{文 献}

1）国立環境研究所：廃棄物埋立処分に起因する有害物 質曝露量の評価手法に関する研究, 国立環境研究所 特別研究報告 SR-28-'99（1999）

2）長谷川陽一，松脇貴晃，吉永 淳，柳沢幸雄，貴田 晶子, 安原昭夫, 中杉修身, 松江秀明, 米沢仲四 郎: 廃棄物のホウ素含有量と溶出量, 環境化学, 11, 17-25 (2001)

3）貴田晶子：廃裹物からのホウ素の溶出, pp750-752, 
第 6 回廃棄物学会研究発表会講演論文集 (1995)

4) Tessier, A., Campbell, P.G.C. and Bisson, M.: Sequential extraction procedure for the speciation of particulate trace metals. Anal. Chem., 51, 844-851 (1979)

5) Yonezawa, C. and Wood, A.K.H.: Prompt gammaray analysis of boron with cold and thermal neutron guided beams. Anal. Chem., 67, 4466-4470 (1995)

6) Kakihana, H., Kotaka, M., Saitoh, S., Nomura, M. and Okamoto, M.: Fundamental studies on the ion- exchange separation of boron isotopes. Bull. Chem. Soc. Japan, 50, 158-163 (1977)

7) Keren, R. and Bingham, F.T.: Boron in water, soil, and plants, Adv. Soil Sci., 1, 229-276 (1985)

8) 大谷倫子, 佐々木喜一, 竹内正博, 幸喜 稔, 田畑 彰久, 川崎睦男, 相澤貴子, 真柄泰基 : 水道水中の ホウ素とその一日全摂取量への寄与に関する研究, 水道協会雑誌, 67, 36-43（1998）

9）田口洋治, 高橋庸介, 岩倉智子, 山口東吾, 馬場貞 雄: 凝集沈殿および吸着による廃水からのホウ素除 去, 環境化学, 11，557-565（2001） 